\title{
The role of school mediation in the development of digital skills among Spanish minors
}

\author{
Maialen Garmendia; Inaki Karrera; Nekane Larrañaga; Carmelo Garitaonandia
}

Nota: Este artículo se puede leer en español en:

http://www.profesionaldelainformacion.com/contenidos/2021/nov/garmendia-karrera-larranaga-garitaonandia_es.pdf

How to cite this article:

Garmendia, Maialen; Karrera, Inaki; Larrañaga, Nekane; Garitaonandia, Carmelo (2021). "The role of school mediation in the development of digital skills among Spanish minors". Profesional de la información, v. 30, n. 6, e300615.

https://doi.org/10.3145/epi.2021.nov.15

Manuscript received on $15^{\text {th }}$ September 2021 Accepted on $18^{\text {th }}$ October 2021
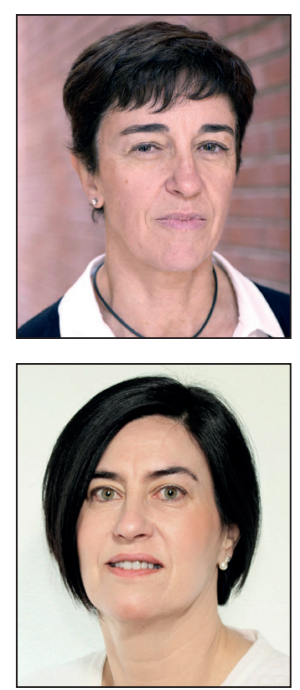

Maialen Garmendia

https://orcid.org/0000-0001-7268-4286

Universidad del País Vasco/Euskal Herriko Unibersitatea

Fac. de Educación, Filosofía y Antropología Edificio II. Plaza Oñati, 3

20018 Donostia San Sebastián

maialen.garmendia@ehu.eus

\section{Nekane Larrañaga \\ https://orcid.org/0000-0002-8062-3544}

Universidad del País Vasco/Euskal Herriko Unibersitatea

Fac. de Educación, Filosofía y Antropología Edificio I. Avda de Tolosa, 70 20018 Donostia San Sebastián nekane.larranaga@ehu.eus

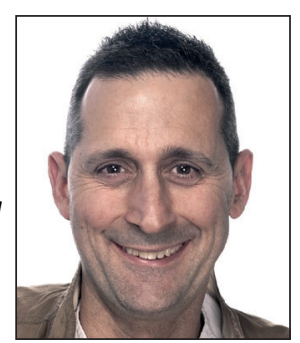

Inaki Karrera $\square$

https://orcid.org/0000-0003-4448-7749

Universidad del País Vasco/Euskal Herriko Unibersitatea

Fac. de Educación, Filosofía y Antropología

Edificio II. Plaza Oñati, 3

20018 Donostia San Sebastián

inaki.karrera@ehu.eus

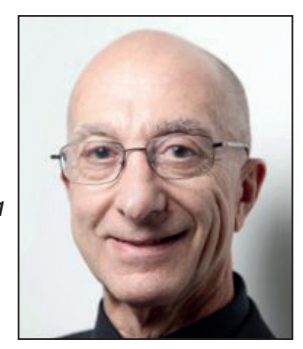

\section{Carmelo Garitaonandia} https://orcid.org/0000-0003-1662-4566

Universidad del País Vasco/Euskal Herriko Unibersitatea

Fac. de Educación, Filosofía y Antropología Edificio I. Avda de Tolosa, 70

20018 Donostia San Sebastián

carmelo.garitaonandia@ehu.eus

\begin{abstract}
Given the growing importance of digital literacy in children's education, this article analyzes the role of school mediation in the development of digital competences among Spanish minors. Based on the results obtained from a survey of 2,900 Spanish schoolchildren between the ages of 9 and 17 years conducted at the end of 2018, we explore their attachment to their school, the digital mediation they receive at the center, and their digital competences. The data show that they have a positive feeling of belonging to their school. The most widespread competences among minors are precisely those most related to the playful use of digital devices. Analysis of the association between school mediation and the acquisition of various types of digital skills shows that mediation is effective in the acquisition of most competences among pre-adolescents, confirming the need for early school mediation. There is no doubt that media and digital education contributes to the achievement of more inclusive environments. Educational policies oriented toward safer use of the Internet and a change in the pedagogical paradigm in primary and secondary education should contribute to enhanced development of digital skills during childhood and adolescence.
\end{abstract}

\section{Keywords}

School mediation; Digital competences; Skills; Internet; School environment; Primary school; Secondary school; Digital skills; Problematic internet use; Technologic education; Educational use of the computer; Literacy; Aptitudes; Abilities; Teenagers; Adolescents; Kids; Girls; Children. 
Acknowledgments

We thank all the contributors to the present article, especially Mr. Charles Edmond Arthur, who corrected the English version.

Funding

This article is a result of a project funded by the Ministry of Economic Affairs and Digital Transformation of Spain (Mineco) [CSO2017-88431-R]; by the National Institute of Cybersecurity (Incibe) of Spain, and by the Innovation and Networks Executive Agency (INEA) of the European Commission [INEA/CEF/ICT/A2018/163442].

\section{Introduction}

Over the last decade, the acceptance and domestic use of Internet and other digital communication technologies within Spanish families has changed substantially (Garmendia et al., 2011; 2016; 2018; 2019; Garitaonandia, 2020). Access to and use of the Internet by Spanish minors and their parents have increased exponentially, as has the use of different devices to access the Internet (Busquet-Durán et al., 2012).

"For most children throughout Europe, smartphones are now the preferred means of going online. This often means they can be connected anytime, anywhere, and the majority of children report using their smartphones daily or almost all the time" (Smahel et al., 2020, p. 6).

In general, a significant percentage of children have contact with the digital environment and the Internet before they start school. On reaching school age, consumption increases with age (Garmendia et al., 2019), and in secondary school, the time spent on the Internet exceeds $4.5 \mathrm{~h}$, or an average of 1,085 h (Qustodio report, 2019).

The age at which children start to access the Internet has decreased (Cánovas et al., 2014; Garmendia et al., 2016), and research by Juhaňák et al. (2019) shows that children who start using computers after the age of 7 show significantly less competence and autonomy in information and communication technologies (ICTs) by age 15 years compared with those who start earlier.

Parental mediation is important within the family, but mediation must also be applied by the various actors responsible for formulating policies or rules to ensure a media environment that is well adapted to the needs and skills of each child, and to the values and priorities of parents; this includes educational institutions, primary schools, and secondary schools (Mascheroni; Vicent, 2016, p. 263). Parents are generally most strict about homework (85\%), followed by the time their children spend on Internet and household chores (56\% for both tasks) (Qustodio report, 2019).

Responsibility for online mediation has mainly been placed on families and parents, whereas the perspective of teachers has received scant attention from researchers. Moreover, when addressing the role of teachers as media educators, the main focus has been on curricular content (Berger, 2020). This article delves into the mediation that takes place at school, not necessarily connected to curriculum content, in an attempt to influence children's natural media behavior (Kalmus, 2013). The aim of this work is to delve deeper into the mediation carried out by teachers at school in order to discover the extent to which this intervention aids children and provides them with tools to make them resilient in the face of risks and avoid possible harm, while enabling them to make the most of opportunities and help improve their digital skills. The school could play an important role in this regard, just as it does in the mediation of addictive behaviors (Cole; Peterson; Smith, 2018).

The debate on essential media skills varies according to the field in question, including communication, entertainment, education, employment, etc., with competences being understood differently from each perspective. Some speak of simpler technical skills, or as Livingstone states, those of a lower level, although one can also consider the competences required for political participation, evaluation of open government, or creative cultural contributions, which are of a higher level (see, for example, the "Greta effect" and online social activism in Ofcom, 2020). Livingstone (2004) defines media education as the ability to access, analyze, evaluate, and create messages in a variety of contexts, proposing that these four components be taught with reference to different media, including the Internet.

\subsection{School mediation and digital competences of minors}

Aguaded (2011) proposes that there is a growing need for media education, or media competence, in order to foster critical, competent citizenship and promote discerning reflection on the information to which we have access. Furthermore, some authors point to a type of schizophrenia that occurs in students, who live in a digital environment yet are "resigned" to the analog world of schools. Accepting official education as a minor annoyance that remains distant from their real interests and needs, students thus become accustomed to living in two parallel worlds (society and school), with little interest in seeking a connection between the two (Gutiérrez-Martín; Tyner, 2012).

In any case, digital competence, or digital literacy, cannot be understood merely as a technical or instrumental issue (Gutiérrez-Martín; Tyner, 2012). Rather, it is also necessary to work on the attitudes and values of school children as 
well (Busquet-Durán et al., 2018). Gutiérrez-Martín and Tyner (2012) highlight two dangers in this sense: the decrease of media education aimed at developing digital competence, and its subsequent reduction to its more technological and instrumental aspects. One of these dangers is also highlighted by Tirado-García and Rodríguez-Arce as follows:

"[...] the practical use of technology has taken on special value to the detriment of tools for perceiving the values that accompany it, and the messages channeled through it, which is why scientific reflection is necessary in order to warn of the risks and opportunities of constant child contact with screens" (Tirado-García; Rodríguez-Arce, 2019, p. 313).

Mesquita-Romero, Fernández-Morante and Cebreiro-López also claim that

"school should be positioned as a basic environment for addressing the collective reflection over the media environments and for preparing the school age citizens for coping constructively with the media impact" (Mesquita-Romero; Fernández-Morante; Cebreiro-López, 2022, p. 2) .

In this regard, strengthening the trust of adolescents in order to prevent problematic internet use can be achieved through appropriate interactions with teachers to help increase the value of the school with regard to peer-group culture (Díaz-Aguado; Martín-Babarro; Falcón, 2018). This is not an easy task, and it is no surprise that resistance to such restorative practices emerges among students who do not understand this approach or have not had any positive experiences with it. Primary and secondary schools must be committed to helping increase positive relationships, social advancement, and emotional intelligence, and to providing young people with skills that they can use forever (Cronin-Lampe; Cronin-Lampe, 2010).

The development of the digital skills of children has now become a necessity for them to be appropriately connected to the world through the Internet. Developing such skills is essential to allow young people to participate in society, education, employment, and the development of their well-being (Van-Deursen; Helsper; Eynon, 2014). Furthermore, improvements in the digital competences they acquire are associated with the diversity of activities they can carry out online. In other words, in addition to using the Internet for communication or entertainment, they should also be capable of using it for other types of participative activity. In this way, young people with higher-level skills will be able to obtain greater benefit from the opportunities offered to them by the Internet (Livingstone; Helsper, 2007; Livingstone et al., 2011; Livingstone; Mascheroni; Stoilova, 2021).

In the EU Kids online 2018 study (Garmendia et al., 2019), in order to analyze the degree of digital inclusion that exists, a scale of digital competences was developed, known as the Internet Skills Scale. This scale identifies 5 areas of competence: instrumental or operational, browsing or information analysis, social skills or the ability to relate to others, creative skills or the ability to create information, and mobile phone skills. This scale was recently reviewed and revalidated by Helsper and colleagues, who identified 4 main types of skill: technical and operational; information, navigation, and processing; communication and interaction; and content creation (Helsper et al., 2021). When gathering the data analyzed herein we were not able to use the new version of the scale. However, the main types of skill remain quite similar to those in the previous scale. As young people develop a variety of these competences to a higher level, they will be better prepared to expand any type of activity they might carry out on the Internet, thus becoming more capable of moving up the ladder of opportunity from a more basic level to one that is more participatory (Livingstone; Helsper, 2007).

\section{Methodology}

We analyze herein the role of schools in the development of digital competences among Spanish minors. The results of this research, carried out within the framework of the EU Kids online IV project, aim to address the following research questions:

1. Do Spanish children and adolescents feel attached to their school? Do they perceive that they have a safe environment and feel supported?

2. What type of digital competences do Spanish minors have (navigation, critical evaluation of information, social, creative, and those associated with mobile media)?

3. Is there an association between the school mediation that minors receive and the development of various types of digital competences?

The data analyzed in this article are based on a sociological survey carried out in Spanish schools using a representative sample of 2,900 girls and boys aged from 9 to 17 years. Of the children surveyed, $51 \%$ were boys and $49 \%$ were girls. A total of 53\% of the children were aged between 9 and 12 years, while $47 \%$ were aged between 13 and 17 years. To ensure that the sample was representative at the national level, schools were selected from the most populous autonomous regions: Madrid, Catalonia, Andalusia, Valencia, Galicia, the Basque Country, and Extremadura. In addition, the sample was stratified according to the environment, with $80 \%$ of the schools located in capital cities and $20 \%$ in smaller municipalities. School ownership was also considered, respecting the proportionality between the two predominant models in Spain: in primary education, $77.84 \%$ of the centers were public while $22.16 \%$ were cofunded; in secondary education, 60.37\% were public while 39.63\% were cofunded. The fieldwork was carried out between October and December 2018. The sample size was determined with a confidence level of $95.5 \%$ and a sampling error margin of $\pm 1.87 \%$. 
The questionnaire uses Likert scales to measure, among other things, the school environment as perceived by the students, as well as the digital skills they have or the mediation they receive from the school with regard to digital skills.

To measure the school environment, a series of items were used to inquire about their feelings towards their school, classmates, or teachers, asking for the degree of agreement with each of these items (QJ1):

(a) I feel like I belong in my school;

(b) I feel safe at school;

(c) Other students are kind and helpful;

(d) Teachers care about me as a person;

(e) There is at least one teacher I can go to if I have a problem.

The Likert scale values range from 1 (Not true) to 4 (Very true).

To measure the digital competence of students, a number of items were used to inquire about their perceived digital skills (QE1):

(a) I know how to save a photo that I find online;

(b) I know how to change my privacy settings (e.g., on a social networking site);

(c) I find it easy to check whether the information I find online is true;

(d) I find it easy to choose the best keywords for online searches;

(e) I know which information I should and should not share online;

(f) I know how to remove people from my contact lists;

(g) I know how to create and post online video or music;

(h) I know how to edit or make basic changes to online content that others have created;

(i) I know how to install apps on a mobile device (e.g., phone or tablet);

(j) I know how to keep track of the costs of mobile app use;

(k) I know how to make an in-app purchase.

Likert scale values range from 1 (Not at all true) to 5 (Totally true).

To measure school mediation, students were asked whether they had ever had any kind of mediation by asking the following question: Have any teachers at your school done these things? The items were:

(a) Suggested ways to use the internet safely;

(b) Encouraged me to explore and learn things on the internet;

(c) Made rules about what I can do on the Internet at school;

(h) Helped me in the past when something has bothered me on the internet (QJ2a-c, h).

Note: Optional questions d), e), f) and g) are not included.

Likert scale values range from 1 (Never), to 5 (Very frequently).

With regard to consent for the survey, we first asked for approval and collaboration from the school administration, then obtained permission from the parents. Data collection was carried out at the school with a researcher present, and the duration of the process was one class hour. Before conducting the survey, the researcher informed the minors about the purpose and protocol of the study, and also indicated that they had the right to refuse to participate in the study or to withdraw at any time. The adolescents were asked to sit with some distance between them to avoid their influencing each other.

\section{Results}

\subsection{The school context}

We first analyzed the school atmosphere and the support that children perceived at school in promoting proper Internet use. There was a positive feeling among the children of belonging to their school, as affirmed by 6 out of 10 (Table 1). This feeling intensified with age and gender, being more deeply rooted among older girls. Thus, more than 7 out of 10 girls between the ages of 13 and 17 years felt a sense of attachment toward their school. On average, 7 out of 10 children stated that they felt safe in their school, and this feeling increased with age. Again, it was older girls who felt most secure at school, with nearly 3 out of 4 teenaged girls affirming this. Trust was high among students. Almost 7 out of 10 expressed trust, for both genders. Girls trusted their classmates more than boys. Trust among students increased with age, indicating that adolescents confided more in their peers.

Of the children, $64 \%$ received support from their teachers, with teenage girls scoring $5 \%$ higher than boys. 
Table 1. School environment and support, by gender and age (\%)

\begin{tabular}{|c|c|c|c|c|c|}
\hline \multirow{2}{*}{ \%"Quite agree" or "Completely" agree } & \multicolumn{2}{|c|}{ 9-12 years old } & \multicolumn{2}{|c|}{$13-17$ years old } & \multirow{2}{*}{ Total } \\
\hline & Boys & Girls & Boys & Girls & \\
\hline I feel that I belong to my school $(\mathrm{N}=2,848)$ & 55 & 60 & 67 & 71 & 63 \\
\hline I feel safe at school $(\mathrm{N}=2,854)$ & 67 & 68 & 70 & 74 & 70 \\
\hline The other students are nice and helpful $(\mathrm{N}=2,853)$ & 64 & 69 & 72 & 76 & 70 \\
\hline The teachers care about me as a person $(\mathrm{N}=2,845)$ & 64 & 67 & 61 & 66 & 64 \\
\hline There is at least one teacher I can talk to if I have a problem $(N=2,840)$ & 64 & 63 & 63 & 65 & 64 \\
\hline
\end{tabular}

EU Kids online 2018 (Garmendia et al., 2019): QJ1a-e. Here are some considerations about your school, classmates, and teachers. Please state the extent to which you agree or disagree with each of these statements. Source: Children and adolescents aged 9-17 years $(\mathrm{N}=2,900)$.

\subsection{Digital competences}

The analysis of digital competences is based on the Internet Skills Scale created and validated by Van-Deursen et al., (2014) of the Oxford Internet Institute. As mentioned above, this scale was recently reviewed (Helsper et al., 2021), after this fieldwork was carried out. This scale distinguishes 5 types of digital skills: instrumental; navigation and critical appraisal of information; social; creative; and skills involving the use of mobile devices (Table 2). The cited table shows how diverse digital skills, or competences, vary according to children's age. Specifically, the data express the percentage of children surveyed who consider each of the proposed statements to be "very true" or "completely true."

Table 2. Digital competences, by age (\%)

\begin{tabular}{|c|c|c|c|c|}
\hline $\begin{array}{c}\text { \% who say the statements } \\
\text { are "Very true" or "Totally } \\
\text { true" }\end{array}$ & Digital competences & $\begin{array}{c}9-12 \\
\text { years old }\end{array}$ & $\begin{array}{c}13-17 \\
\text { years old }\end{array}$ & Total \\
\hline \multirow{2}{*}{ Instrumental } & I know how to save a photo I find online & 45 & 75 & 59 \\
\hline & I know how to change my privacy settings & 43 & 83 & 62 \\
\hline \multirow{2}{*}{ Navigation and information } & It is easy to choose the keywords for online searches & 25 & 38 & 31 \\
\hline & It is easy to check whether the information I find online is true & 36 & 56 & 45 \\
\hline \multirow{2}{*}{ Social } & I know how to remove people from my contact list & 69 & 87 & 78 \\
\hline & I know what information I can and cannot share online & 66 & 91 & 78 \\
\hline \multirow{2}{*}{ Creative } & I know how to create and publish videos or music online & 44 & 68 & 55 \\
\hline & I know how to edit or make changes to content that others have created & 20 & 29 & 24 \\
\hline \multirow{3}{*}{ Mobile digital media } & I know how to install applications on mobiles & 85 & 96 & 90 \\
\hline & I know how to track usage costs & 28 & 54 & 41 \\
\hline & I know how to make an online purchase & 43 & 64 & 53 \\
\hline
\end{tabular}

EU Kids online 2018 (Garmendia et al., 2019): QE1a-k. On a scale of 1 to 5, where 1 is "Not true for me" and 5 is "Totally true," how true are these statements for you? Please mark one number on each line.

Source: Children and adolescents aged $9-17$ years $(N=2,900)$.

\subsubsection{Instrumental competences}

Slightly more than half the children claimed to have the instrumental skills they were asked about: $59 \%$ know how to save a photo they find online, and $62 \%$ know how to change their privacy settings. The differences according to age are very clear. Among children up to the age of 12 , the percentage of those who claim to have these skills is more than $40 \%$, while among the older ones, this number is higher: 3 out of 4 know how to save a photograph, while $83 \%$ know how to change their privacy settings.

\subsubsection{Navigation skills and critical appraisal of information}

Of the children surveyed, $45 \%$ stated that it was totally true or quite true that they find it easy to check whether the information they find online is correct. Of the children, $31 \%$ stated that they find it easy to choose keywords for online searches. The difference in competences between the two age groups of 9-12 years and those over 13 years was 13 and $20 \%$, respectively. The average level of information competence of Spanish adolescents on a scale from 1 to 10 is 6 . In general, as described above, the level of competence is strongly influenced by age.

\subsubsection{Social competences}

Social skills are highly prevalent among Spanish children and adolescents. More than 3 out of 4 (78\%) stated that it is totally true or quite true that they know how to remove people from their contact list, and they also say they know which 
information they can and cannot share online. These skills also vary substantially by age. The difference between boys and girls aged 9-12 and 13-17 years is 25\% regarding which information they can share, while this difference reduced to $18 \%$ with regard to elimination of contacts. The average level of social skills is 8.3 on a scale from 1 to 10 . Although this value increases with age, the level for girls and younger boys is also relatively high.

\subsubsection{Creative competences}

Of the children surveyed, $55 \%$ stated that they know how to create and publish music videos online, while only $24 \%$ know how to edit or make basic changes to online content created by others. Creative skills increase with age, with some differences according to gender. Among the 9-12-year-olds, $20 \%$ of boys and girls know how to edit or make basic changes to online content created by others, while among teenagers, this number increases to $29 \%$. The data show that creative skills for video and music production are widespread among both pre-teens $(44 \%)$ and teens $(68 \%)$. The overall rate of creative skills is 5.7 .

\subsubsection{Competences associated with mobile digital media}

Although the smartphone has become the principal means of Internet access for children and young people aged 9-17 years, mobile skills are unevenly distributed in Spain, as in other countries. Of the children, $90 \%$ say they know how to install applications on a smartphone or tablet, but only slightly more than half (53\%) know how to make purchases through an application, and only slightly more than $40 \%$ know how to track the cost of using an application. These skills vary greatly according to age. Overall, the differences between pre-teens and teens are between 11 and $26 \%$, respectively. The less widespread a skill, the greater the difference by age. In summary, skills associated with mobile digital media show a general average of 8.1 points out of 10, revealing that these competences are widespread among Spanish children and adolescents.

\subsection{Mediation by teachers}

Teacher involvement in mediating children's Internet use is relatively low (Table 3). Only 1 in 4 stated that teachers had suggested safe ways of using the Internet. The youngest children received this type of advice more often, although the differences are small, or even inexistent, in the case of girls.

The promotion of Internet use by teachers is somewhat more frequent. The support that children stated that they received from their teachers in terms of encouraging them to discover and learn things on the Internet is somewhat higher. Around $29 \%$ of children perceived this to be the case, with no differences according to age or gender. However, establishing restrictions is more widespread, reaching $39 \%$. Older children, especially girls (46\%), are more likely to report these restrictions than boys (42\%).

There is much less intervention by teachers in offering children help when something bad happened to them on the Internet. Only $11 \%$ claim to have received such support, rising slightly to $13 \%$ among pre-adolescent girls.

Table 3. School mediation, by gender and age group (\%)

\begin{tabular}{|c|c|c|c|c|c|}
\hline \multirow[b]{2}{*}{$\%$ of those who answer "Often" or "Almost always" } & \multicolumn{2}{|c|}{$9-12$ years old } & \multicolumn{2}{|c|}{$13-17$ years old } & \multirow{2}{*}{ Total } \\
\hline & Boys & Girls & Boys & Girls & \\
\hline My teacher has suggested ways for me to use the Internet safely $(\mathrm{N}=2,852)$ & 26 & 24 & 22 & 24 & 25 \\
\hline My teacher has encouraged me to discover and learn things on the Internet $(\mathrm{N}=2,847)$ & 30 & 28 & 29 & 29 & 29 \\
\hline My teacher has established rules about what I can do online at school $(\mathrm{N}=2,844)$ & 34 & 33 & 42 & 46 & 39 \\
\hline My teacher has helped me in the past when something bothered me on the Internet $(\mathrm{N}=2,828)$ & 13 & 10 & 11 & 10 & 11 \\
\hline
\end{tabular}

EU Kids online 2018 (Garmendia et al., 2019): QJ2a-c, h. Have any of the teachers at your school done any of these things? Source: Children and young people aged $9-17$ years $(N=2,900)$

\subsection{Association between school mediation and digital competence of minors according to age group}

This section aims to analyze the relative effectiveness of school mediation by using the efficacy of the development of various digital competences as an indicator. Thus, if the results of the analysis show a significant increase in the development of competences among minors who have received a certain type of mediation "frequently" or "very frequently," we can affirm that this mediation is effective. The analysis also considers the effect of age to reveal more clearly how mediation affects skills by analyzing the two age groups (9-12 and 13-17 years) independently. In other words, considering the possibility that they will react differently to mediation, the influence of mediation on pre-adolescents and adolescents is analyzed separately.

In general, the online mediation that children receive at school is associated with increased digital competences, albeit not homogeneously.

For children aged 9-12 years, frequent or very frequent mediation results in a significantly higher level of competence in nearly all the skills analyzed. Similarly, in most cases in which there has been a certain amount of frequent school mediation, their skills improved, showing statistically significant differences compared with those who received such mediation less frequently (Table 4). 
Table 4. Active school mediation for security and usage: competence by age group (\%)

\begin{tabular}{|c|c|c|c|c|c|c|c|}
\hline \multirow{2}{*}{\multicolumn{2}{|c|}{ Competence }} & \multirow{2}{*}{\multicolumn{3}{|c|}{$\begin{array}{c}\text { Active school mediation for } \\
\text { safety } \\
\begin{array}{c}\text { My teacher has suggested } \\
\text { ways for me to use the Inter- } \\
\text { net safely }\end{array}\end{array}$}} & \multirow{2}{*}{\multicolumn{3}{|c|}{$\begin{array}{l}\text { Active school mediation for } \\
\text { usage } \\
\text { My teacher has encouraged } \\
\text { me to discover and learn } \\
\text { things on the Internet }\end{array}$}} \\
\hline & & & & & & & \\
\hline \%"Quite true" or "Totally true" & 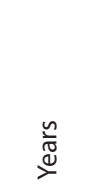 & 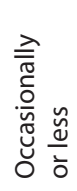 & 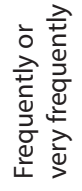 & 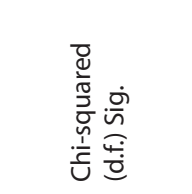 & 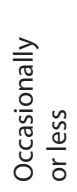 & 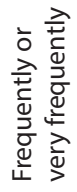 & 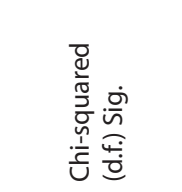 \\
\hline \multicolumn{8}{|l|}{ Instrumental } \\
\hline \multirow{2}{*}{ I know how to save a photo I find on Internet } & $9-12$ & 44 & 57 & $14.757(1) .000$ & 41 & 63 & $45.198(1) .000$ \\
\hline & $13-17$ & 74 & 79 & 2.137 (1) .144 & 73 & 81 & 7.462 (1).006 \\
\hline \multirow{2}{*}{ I know how to change my privacy settings } & $9-12$ & 40 & 55 & $19.303(1) .000$ & 40 & 55 & 22.788 (1).000 \\
\hline & $13-17$ & 83 & 82 & $0.213(1) .644$ & 82 & 85 & $1.552(1) .213$ \\
\hline \multicolumn{8}{|l|}{ Navigation \& information } \\
\hline \multirow{2}{*}{ It is easy to select key words for online searches } & $9-12$ & 21 & 40 & 40.013 (1).000 & 20 & 40 & 48.727 (1) .000 \\
\hline & $13-17$ & 37 & 40 & 1.252 (1).263 & 35 & 44 & 9.373 (1) .002 \\
\hline \multirow{2}{*}{ It is easy to check whether the information I find online is correct } & $9-12$ & 33 & 49 & 22.621 (1).000 & 32 & 52 & 41.533 (1).000 \\
\hline & $13-17$ & 57 & 56 & $0.084(1) .772$ & 55 & 61 & 3.675 (1) .055 \\
\hline \multicolumn{8}{|l|}{ Social } \\
\hline \multirow{2}{*}{ I know how to remove people from my contact list } & $9-12$ & 69 & 78 & $8.851(1) .003$ & 69 & 80 & $14.232(1) .000$ \\
\hline & $13-17$ & 87 & 89 & $0.482(1) .487$ & 87 & 89 & 0.827 (1) .363 \\
\hline \multirow{2}{*}{ I know what information I can and cannot share online } & $9-12$ & 65 & 78 & $15.85(1) .000$ & 64 & 79 & $24.754(1) .000$ \\
\hline & $13-17$ & 91 & 90 & $0.185(1) .667$ & 91 & 91 & $0.103(1) .749$ \\
\hline \multicolumn{8}{|l|}{ Creative } \\
\hline \multirow{2}{*}{ I know how to create and publish videos or music online } & $9-12$ & 42 & 54 & 13.102 (1) .000 & 41 & 56 & 21.351 (1).000 \\
\hline & $13-17$ & 68 & 69 & 0.246 (1) .620 & 66 & 75 & 9.577 (1).002 \\
\hline \multirow{2}{*}{$\begin{array}{l}\text { I know how to edit or make basic changes to online content that } \\
\text { others have created }\end{array}$} & $9-12$ & 19 & 23 & $2.553(1) .110$ & 18 & 24 & $5.645(1) .018$ \\
\hline & $13-17$ & 28 & 30 & $0.235(1) .628$ & 26 & 34 & $7.737(1) .005$ \\
\hline \multicolumn{8}{|l|}{ Mobile digital media } \\
\hline \multirow{2}{*}{ I know how to install applications on mobiles } & $9-12$ & 86 & 91 & $3.674(1) .055$ & 85 & 93 & $12.875(1) .000$ \\
\hline & $13-17$ & 96 & 97 & 0.843 (1).359 & 96 & 97 & $0.63(1) .427$ \\
\hline \multirow{2}{*}{ I know how to track usage costs } & $9-12$ & 27 & 37 & $9.632(1) .002$ & 27 & 36 & $10.637(1) .001$ \\
\hline & $13-17$ & 52 & 60 & $5.037(1) .025$ & 51 & 61 & $9.499(1) .002$ \\
\hline \multirow{2}{*}{ I know how to make an online purchase } & $9-12$ & 42 & 53 & $11.364(1) .001$ & 42 & 51 & $8.932(1) .003$ \\
\hline & $13-17$ & 63 & 68 & 2.102 (1).147 & 63 & 69 & 3.564 (1) .059 \\
\hline
\end{tabular}

Chi-squared, significance $p<.01, p<.05$ for 99\% NA and 95\% NA, respectively. EU Kids online 2018 (Garmendia et al., 2019): QJ1a-e. Have any of the teachers at your school done any of these things? QE1a-k on a scale from 1 to 5 , where 1 is "Not true" and 5 is "Totally true," How true are these statements for you? Please mark one number on each line.

Source: Children and adolescents aged 9-17 years $(\mathrm{N}=2,900)$.

Applying the chi-squared statistical test, we found that, among children aged 9-12 years, there is a strong association between active school mediation regarding safety and use, restrictive and helpful school mediation, and instrumental competences $(p<0.05)$. Therefore, among those children who received such mediation, the scores in these competencies are significantly higher. However, among adolescent boys and girls aged 13-17 years, there is no significant difference in competences based on the frequency of the mediation received. 
Table 5. Restrictive and helpful school mediation: competence by age group (\%)

\begin{tabular}{|c|c|c|c|c|c|c|c|}
\hline \multirow{2}{*}{\multicolumn{2}{|c|}{ Competence }} & \multirow{2}{*}{\multicolumn{3}{|c|}{$\begin{array}{c}\text { Restrictive school mediation } \\
\text { My teacher has established rules } \\
\text { about what I can do on the Internet } \\
\text { at school }\end{array}$}} & \multirow{2}{*}{\multicolumn{3}{|c|}{$\begin{array}{l}\text { Helpful school mediation } \\
\text { My teacher has helped me when } \\
\text { something has bothered me on the } \\
\text { Internet }\end{array}$}} \\
\hline & & & & & & & \\
\hline \% "Quite true" or "Totally true" & 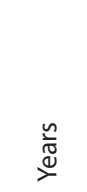 & 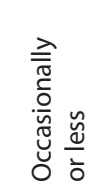 & 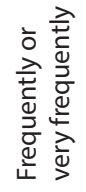 & 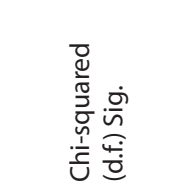 & 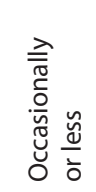 & 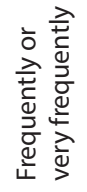 & 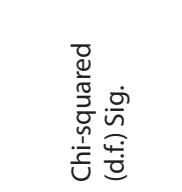 \\
\hline \multicolumn{8}{|l|}{ Instrumental } \\
\hline \multirow{2}{*}{ I know how to save a photo I find on Internet } & $9-12$ & 42 & 59 & 27.639 (1).000 & 46 & 60 & $8.888(1) .003$ \\
\hline & $13-17$ & 74 & 78 & $3.518(1) .061$ & 76 & 74 & $0.227(1) .634$ \\
\hline \multirow{2}{*}{ I know how to change my privacy settings } & $9-12$ & 38 & 55 & $30.515(1) .000$ & 41 & 57 & $11.207(1) .001$ \\
\hline & $13-17$ & 82 & 84 & $0.976(1) .323$ & 83 & 82 & $0.262(1) .608$ \\
\hline \multicolumn{8}{|l|}{ Navigation \& information } \\
\hline \multirow{2}{*}{ It is easy to select key words for online searches } & $9-12$ & 21 & 36 & $28.23(1) .000$ & 24 & 32 & $3.466(1) .063$ \\
\hline & $13-17$ & 36 & 39 & $1.228(1) .268$ & 37 & 46 & $3.626(1) .057$ \\
\hline \multirow{2}{*}{$\begin{array}{l}\text { It is easy to check whether the information } \\
\text { I find online is correct }\end{array}$} & $9-12$ & 31 & 49 & $33.814(1) .000$ & 35 & 53 & $14.141(1) .000$ \\
\hline & $13-17$ & 56 & 57 & $0.233(1) .630$ & 57 & 54 & $0.353(1) .552$ \\
\hline \multicolumn{8}{|l|}{ Social } \\
\hline \multirow{2}{*}{ I know how to remove people from my contact list } & $9-12$ & 65 & 86 & $52.537(1) .000$ & 71 & 75 & 0.594 (1) .441 \\
\hline & $13-17$ & 86 & 90 & 4.802 (1).028 & 89 & 79 & 9.393 (1).002 \\
\hline \multirow{2}{*}{$\begin{array}{l}\text { I know what information I can } \\
\text { and cannot share online }\end{array}$} & $9-12$ & 63 & 77 & 23.495 (1) .000 & 66 & 81 & $11.274(1) .001$ \\
\hline & $13-17$ & 90 & 91 & $0.467(1) .494$ & 91 & 90 & 0.275 (1) .600 \\
\hline \multicolumn{8}{|l|}{ Creative } \\
\hline \multirow{2}{*}{$\begin{array}{l}\text { I know how to create and publish videos or music } \\
\text { online }\end{array}$} & $9-12$ & 40 & 53 & 18.497 (1) .000 & 43 & 57 & $8.901(1) .003$ \\
\hline & $13-17$ & 71 & 64 & $6.482(1) .011$ & 68 & 72 & $0.825(1) .364$ \\
\hline \multirow{2}{*}{$\begin{array}{l}\text { I know how to edit or make basic changes to } \\
\text { online content that others have created }\end{array}$} & $9-12$ & 19 & 22 & $2.163(1) .141$ & 19 & 24 & $1.561(1) .212$ \\
\hline & $13-17$ & 30 & 27 & $1.758(1) .185$ & 28 & 43 & $12.581(1) .000$ \\
\hline \multicolumn{8}{|l|}{ Mobile digital media } \\
\hline \multirow{2}{*}{ I know how to install applications on mobiles } & $9-12$ & 84 & 94 & 19.908 (1) .000 & 87 & 93 & $3.72(1) .054$ \\
\hline & $13-17$ & 96 & 98 & 4.395 (1) .036 & 97 & 95 & 0.787 (1) .375 \\
\hline \multirow{2}{*}{ I know how to track usage costs } & $9-12$ & 27 & 34 & 5.373 (1).020 & 28 & 41 & $8.011(1) .005$ \\
\hline & $13-17$ & 54 & 54 & $0.103(1) .748$ & 54 & 61 & 1.898 (1).168 \\
\hline \multirow{2}{*}{ I know how to make an online purchase } & $9-12$ & 41 & 50 & 6.559 (1).010 & 43 & 56 & 7.149 (1) .008 \\
\hline & $13-17$ & 66 & 63 & 0.703 (1) .402 & 65 & 68 & $0.514(1) .473$ \\
\hline
\end{tabular}

Chi-squared, significance $p<.01, p<.05$ for 99\% NA and 95\% NA, respectively. EU Kids online 2018 (Garmendia et al., 2019): QJ1a-e. Have any of the teachers at your school done any of these things? QE1a-k on a scale from 1 to 5 , where 1 is "Not true" and 5 is "Totally true," how true are these statements for you? Please mark one number on each line.

Source: Children and adolescents aged 9-17 years $(\mathrm{N}=2,900)$.

As in the case of instrumental competences, applying the chi-squared statistical test to analyze navigation competences and critical appraisal of information, we again found that, among boys and girls aged 9-12 years, there is a strong association between the frequency of active school mediation in safety and use, restrictive and helpful mediation, and navigation competences and critical appraisal of information, with the only exception being helpful school mediation and skills related to the selection of search words. Pre-adolescents who received frequent mediation often display a significantly higher prevalence of skills than those who have not received frequent mediation. However, among teenage boys and girls aged 13-17 years, there is no significant difference except in the case of active school mediation and the ability to choose keywords for online searches. Applying the chi-squared statistical test to social competences, the results are quite similar again. On the one hand, we again found that, in children aged 9-12 years, there is a strong association between active school mediation in safety and use, restrictive and supportive mediation, and social competences, except in the case of helpful mediation and the removal of people from their contact lists. 
However, among adolescent boys and girls aged 13-17 years, there is no significant difference in social competences based on mediation, with the exception of helpful mediation in the elimination of contacts. It is interesting to note that helpful school mediation does not influence the elimination of contacts among pre-teens, but it does among teenagers.

Regarding the different types of school mediation and creative competences, application of the chi-squared statistical test resulted in quite different results from those described above. On the one hand, we found that, among children aged 9-12 years, there is a strong association between active school mediation for safety and use, restrictive and helpful mediation, and the competences of creating and publishing videos and music online. However, there is no significant association between mediation and the ability to edit or make basic changes to online content that others have created. On the other hand, among teenage boys and girls aged 13-17 years, there is no significant difference, except in the case of active school mediation in the use and creation of videos, and in school mediation to help with the skill of editing content created by others.

Probably the most diverse relationship exists between different types of school mediation and the competences associated with mobile digital media. Among 9-12-year-olds, there is a significant association between active mediation in usage and restrictive mediation in relation to children's ability to install mobile applications. In the same way, monitoring usage costs is associated with security mediation and active mediation for usage. Likewise, skills related to online purchases are associated with active security mediation as well as active usage mediation. However, there is no significant association between mediation and mobile skills among adolescents, except with regard to monitoring usage costs and active school mediation in the use of mobile equipment. We are not surprised by the uneven influence of school mediation on the skills associated with mobile digital media, as these are precisely the devices that are least used in the school environment, and other actors may have more influence on the acquisition of these skills as well.

\section{Discussion}

Although children feel that school is a place where they belong, where they have teachers who are supportive and willing to help them, teachers do not monitor their online activities and tend to be more restrictive (39\%) rather than proactive $(29 \%)$ in their recommendations. Moreover, they are more restrictive with adolescents (43\%) than with pre-teens (33\%).

The most prevalent skills among Spanish children are social competences, followed by those associated with mobile digital media and those that are instrumental. Note that these results on digital competencies could be overestimated given the self-report nature of questionnaires (Aesaert et al., 2017).

However, analysis of the association between school mediation frequency and the various types of competences shows it to be effective in the acquisition of most skills among pre-adolescents. Thus, the prevalence of most skills is significantly higher among pre-teens who received frequent or very frequent school mediation than among those who received it less frequently. However, this is not the case with teenagers. There are very few competences that display a significant difference depending on the school mediation received by adolescents. One may thus think that adolescents acquire these competences through other agents, friends, or other adults, or in other social environments outside school.

This evidence supports the idea that school mediation is effective in the development of competences among pre-adolescents, yet this group shows significant differences in the development of skills when comparing those who received various types of school mediation. However, the data show that early school mediation is effective in developing almost all digital competences.

The least widespread digital skills among both pre-adolescent and adolescent Spanish schoolchildren are creative or navigational skills, such as knowing how to make changes to content created by others or knowing how to choose keywords for searches. It is especially relating to teaching these two types of skills (i.e., creative and navigational) where it would be advisable for teachers to become more proactive.

After the initial euphoria that accompanied Web 2.0 and the development of theories about the emergence of a "participatory culture," a more critical and thoughtful interpretation now prevails, emphasizing that many people who use the Internet, and in particular social platforms and networks, do not produce content but are basically consumers of content created by others. Thus, the overall index of creative skills is 5.7 (on a scale from 1 to 10), revealing that both pre-adolescent and adolescent Spanish students still have ample room for improvement in these types of competences. The school could play an important role in these areas.

The debate over the issue of digital inequality as it relates to both material and social inequities (Van-Deursen; Van-Dijk, 2013) is a controversy that must also be taken into account in future studies. It is not surprising that students at the same school might have different digital skills. Thus, while some students interact in virtual spaces with total mastery, some of their classmates limit their online experiences to the consumption of digital content and are totally oblivious to the fact that they do not have access to certain opportunities. This situation points to the social inequality that exists from childhood, and some authors have identified this as the second digital divide, an issue that poses a major challenge to achieving inclusive schooling in the digital realm as well. For this reason, there is a clear need to incorporate media education into the school curriculum (Aparici et al., 2010). 
Not all children and adolescents are reaping the benefits of the digital age, either because their parents do not know how to guide or direct them, or because society still does not offer them enough resources that are imaginative and appropriate (Livingstone, 2018). Furthermore, as shown by research regarding the "ladder of opportunities" (Livingstone; Helsper, 2007; Ofcom, 2020), few children have the motivation and digital skills required to create their own content online or become creators who are expressive, critical, or active in the context of social participation, as called for by both children's rights advocates and young people themselves (Ito et al., 2013) in the current digital age. Livingstone, Mascheroni and Stoilova (2021, p. 22) recommend that

"future research examining the relationship between children's digital access, activities and outcomes should include measures of digital skills."

Helsper (2021) suggests that such research could guide policy interventions that address future needs in an increasingly digitalized society, also helping to prevent those in a more disadvantaged position form suffering harm due to the digitization of society.

Finally, we comment on the limitations of this study, of which we are fully aware. Certainly, the most important limitation relates to the dates when this information was collected, since the questionnaire was administered just before the Covid-19 pandemic. This leads us to consider it appropriate to gather new information on similar aspects to allow a better and more up-to-date interpretation of the data and conclusions presented herein, as we know the pandemic has boosted ICT use in schools.

\section{References}

Aesaert, Koen; Voogt, Joke; Kuiper, Els; Van-Braak, Johan (2017). “Accuracy and bias of ICT self-efficacy: An empirical study into students' over-and underestimation of their ICT competences". Computers in human behavior, v. 75, pp. 92-102. https://doi.org/10.1016/j.chb.2017.05.010

Aguaded, Ignacio (2011). "Media education: An international unstoppable phenomenon. The work of the UN, Europe and Spain in the field of edu-communication". Comunicar, n. 37, pp. 7-8.

https://doi.org/10.3916/C37-2011-01-01

Aparici, Roberto; Campuzano, Antonio; Ferrés, Joan; García-Matilla, Agustín (2010). La educación mediática en la escuela 2.0 .

http://antoniocampuzano.es/wp-content/uploads/2015/04/La-Educaci\%C3\%B3n-Medi\%C3\%A1tica-en-la-Escuela-2.0.pdf

Berger, Priscila (2020). "Teachers' mediation practice: Opportunities and risks for youth media behavior". Comunicar, n. 64, pp. 49-59.

https://doi.org/10.3916/C64-2020-05

Busquet-Durán, Jordi; Ballano-Macías, Sonia; Medina-Cambrón, Alfons; Sastre-Freixa, Xavi R.; Esteban, Adrià (2018) "La encrucijada de la educación en la era digital. El reto de las TIC en las escuelas. En: Jiménez-Iglesias, Estefanía; Garmendia, Maialen; Casado, Miguel A. (coords.). Entre selfies y whatsapps. Oportunidades y riesgos para la infancia y la adolescencia conectada. Barcelona: Gedisa. ISBN: 9788416919871

https://clea.edu.mx/biblioteca/files/original/369cf669df5444c8747192ef7c177d10.pdf

Busquet-Durán, Jordi; Ballano-Macías, Sonia; Medina-Cambrón, Alfons; Uribe-Sandoval, Ana-Cinthya (2012). “La dinámica de la brecha digital entre jóvenes, padres y profesores en España”. En: García-Jiménez, Antonio. Comunicación, infancia y juventud. Barcelona: UOC, pp. 39-55. ISBN: 9788490290248

https://www.researchgate.net/publication/272481531_La_dinamica_de_la_Brecha_digital_entre_Jovenes_Padres_y_ Profesores_en_Espana

Cánovas, Guillermo; García-de-Pablo, Alicia; Oliaga-San-Atilano, Ana; Aboy-Ferrer, Isabel (2014). Menores de edad y conectividad móvil en España: tablets y smartphones. Asociación Protégeles.

https://kidsandteensonline.files.wordpress.com/2014/07/estudio_movil_smartphones_tablets_protegeles.pdf

Cole, Hayley A.; Peterson, Sarah J.; Smith, Gregory T. (2018). "Elementary and middle school predictors of high school drinking problems and maladaptive coping". Addictive behaviors, v. 87, pp. 177-182.

https://doi.org/10.1016/j.addbeh.2018.07.010

Cronin-Lampe, Kath; Cronin-Lampe, Ron (2010). “Developing a restorative school culture: The blending of a personal and professional 'pilgrimage'”. Explorations: An e-journal of narrative practice, n. 1, pp. 14-33.

https://www.pilgrimpractices.co.nz/explorations.pdf

Díaz-Aguado, María-José; Martín-Babarro, Javier; Falcón, Laia (2018). “Problematic internet use, maladaptive future time perspective and school context". Psicothema, v. 30, n. 2, pp. 195-200.

https://doi.org/10.7334/psicothema2017.282 
Garitaonandia, Carmelo; Karrera, Inaki; Jiménez-Iglesias, Estefanía; Larrañaga, Nekane (2020). “Menores conectados y riesgos online: Contenidos inadecuados, uso inapropiado de la información y uso excesivo de internet". Profesional de la información, v. 29, n. 4.

https://doi.org/10.3145/epi.2020.jul.36

Garmendia, Maialen; Casado, Miguel-Ángel; Jiménez-Iglesias, Estefanía; Garitaonandia, Carmelo (2018). “Oportunidades, riesgos, daño y habilidades digitales de los menores españoles". En: Jiménez-Iglesias, Estefanía; Garmendia, Maialen; Casado, Miguel A. (coords.). Entre selfies y whatsapps. Oportunidades y riesgos para la infancia y la adolescencia conectada. Barcelona: Gedisa, pp. 31-54. ISBN: 9788416919871

https://clea.edu.mx/biblioteca/files/original/369cf669df5444c8747192ef7c177d10.pdf

Garmendia, Maialen; Garitaonandia, Carmelo; Martínez, Gemma; Casado, Miguel-Ángel (2011). Riesgos y seguridad en internet: Los menores españoles en el contexto europeo. Bilbao: Universidad del País Vasco; EU Kids Online. ISBN: 978 8498605204

https://www.observatoriodelainfancia.es/ficherosoia/documentos/3155_d_Informe_EU_Kids_Online_Espa\%C3\%B1a_ completo_red.pdf

Garmendia, Maialen; Jiménez-Iglesias, Estefanía; Casado, Miguel-Ángel; Mascheroni, Giovanna (2016). Net children go mobile. Riesgos y oportunidades en internet y uso de dispositivos móviles entre menores españoles (2010-2015). Madrid: Red.es/Universidad del País Vasco.

https://netchildrengomobile.eu/ncgm/wp-content/uploads/2013/07/Net-Children-Go-Mobile-Spain.pdf

Garmendia, Maialen; Jiménez-Iglesias, Estefanía; Karrera, Inaki; Larrañaga, Nekane; Casado, Miguel-Ángel; Martínez, Gemma; Garitaonandia, Carmelo (2019). Actividades, mediación, oportunidades y riesgos online de los menores en la era de la convergencia mediática. Instituto Nacional de Ciberseguridad (Incibe); Universidad del País Vasco. ISBN: 978 8409122424

https://www.is4k.es/sites/default/files/contenidos/informe-eukidsonline-2018.pdf

Gutiérrez-Martín, Alfonso; Tyner, Kathleen (2012). "Media education, media literacy and digital competence". Comunicar, n. 38, pp. 31-39.

https://doi.org/10.3916/C38-2012-02-03

Helsper, Ellen J.; Schneider, Luc S.; Van-Deursen, Alexander J. A. M.; Van-Laar, Ester (2021). The youth digital skills indicator: Report on the conceptualisation and development of the ySkills digital skills measure. KU Leuven, Leuven: ySkills. https://zenodo.org/record/4608010

Ito, Mizuko; Gutiérrez, Kris D.; Livingstone, Sonia; Penuel, Bill; Rhodes, Jean; Salen, Katie; Schor, Juliet; Sefton-Green, Julian; Watkins, S. Craig (2013). Connected learning: An agenda for research and design. Irvine, CA: The Digital Media and Learning Research Hub Reports on Connected Learning.

https://dmlhub.net/publications/connected-learning-agenda-for-research-and-design/index.html

Juhaňák, Libor; Zounek, Jiří; Záleská, Klára; Bárta, Ondřej; Vlčková, Kristýna (2019). “The relationship between the age at first computer use and students' perceived competence and autonomy in ICT usage: A mediation analysis". Computers \& education, n. 14, 103614.

https://doi.org/10.1016/j.compedu.2019.103614

Kalmus, Veronica (2013). "Making sense of the social mediation of children's internet use: Perspectives for interdisciplinary and cross-cultural research". In: Wijnen, Christine W.; Trültzsch, Sascha; Ortner, Christina (eds.). Medienwentel im wandel: Kommunicationswissenchaftliche positionen, perspektiven und Konsequenzen, pp. 137-149. Springer. ISBN: 978 3531184364 https://doi.org/10.1007/978-3-531-19049-5_11

Livingstone, Sonia (2004). “What is media literacy?". Intermedia, v. 32, n. 3, pp. 18-20.

http://eprints.Ise.ac.uk/1027/1/What_is_media_literacy_\%28LSERO\%29.pdf

Livingstone, Sonia (2018). "La vida online de la infancia”. En: Jiménez-Iglesias, Estefanía; Garmendia, Maialen; Casado, Miguel A. (coords.). Entre selfies y whatsapps. Oportunidades y riesgos para la infancia y la adolescencia conectada. Barcelona: Gedisa, pp. 31-54. ISBN: 9788416919871

https://clea.edu.mx/biblioteca/files/original/369cf669df5444c8747192ef7c177d10.pdf

Livingstone, Sonia; Haddon, Leslie; Görzig, Anke; Ólafsson, Kjartan (2011). Risks and safety on the internet: The perspective of European children. Full findings. LSE, EU Kids Online. https://ibdigital.uib.es/greenstone/sites/localsite/collect/portal_social/index/assoc/varis000/8.dir/varis0008.pdf

Livingstone, Sonia; Helsper, J. Ellen (2007). "Gradations in digital inclusion: children, young people and the digital divide". New media and society, v. 9, n. 4, pp. 671-696.

https://doi.org/10.1177/1461444807080335 
Livingstone, Sonia; Mascheroni, Giovanna; Stoilova, Mariya (2021). "The outcomes of gaining digital skills for young people's lives and wellbeing: A systematic evidence review". New media \& society, first online.

https://doi.org/10.1177/14614448211043189

Mascheroni, Giovanna; Vincent, Jane (2016). "Perpetual contact as a communicative affordance: opportunities, constraints and emotions". Mobile media and communication, v. 4, n. 3, pp. 310-326.

https://doi.org/10.1177/2050157916639347

Mesquita-Romero, Walter-Antonio; Fernández-Morante, M. Carmen; Cebreiro-López, Beatriz (2022). “Critical media literacy to improve students' competencies". Comunicar, n. 70, p. 47-57.

https://doi.org/10.3916/C70-2022-04

Ofcom (2020). Children and parents: Media use and attitudes report 2019.

https://www.ofcom.org.uk/research-and-data/media-literacy-research/childrens

Qustodio Report (2019).

https://qweb.cdn.prismic.io/qweb/652ec17d-790d-49a5-8236-713c96b2c732_20191022_familias_hiperconectadas_es.pdf

Smahel, David; Machackova, Hana; Mascheroni, Giovanna; Dedkova, Lenka; Staksrud, Elisabeth; Ólafsson, Kjartan; Livingstone, Sonia; Hasebrink, Uwe (2020). EU Kids online 2020: Survey results from 19 countries. EU Kids Online.

https://www.Ise.ac.uk/media-and-communications/assets/documents/research/eu-kids-online/reports/EU-KidsOnline-2020-March2020.pdf

Tirado-García, Alejandra; Rodríguez-Arce, María (2019). “Educación mediática en la era digital: hacia la formación de internautas exigentes". adComunica, n. 18, pp. 313-316.

https://doi.org/10.6035/2174-0992.2019.18.18

Van-Deursen, Alexander J. A. M.; Helsper, Ellen; Eynon, Rebecca (2014). Measuring digital skills. From digital skills to tangible. Outcomes project report.

https://www.Ise.ac.uk/media-and-communications/assets/documents/research/projects/disto/Measuring-DigitalSkills.pdf

Van-Deursen, Alexander J. A. M.; Van-Dijk, Jan A. G. M. (2013). "The digital divide shifts to differences in usage”. New media and society, v. 16, n. 3, pp. 507-526.

https://doi.org/10.1177/1461444813487959

\section{Inforảrea}

Ayudamos a tu organización en la transformación digital yel gobierno de la información

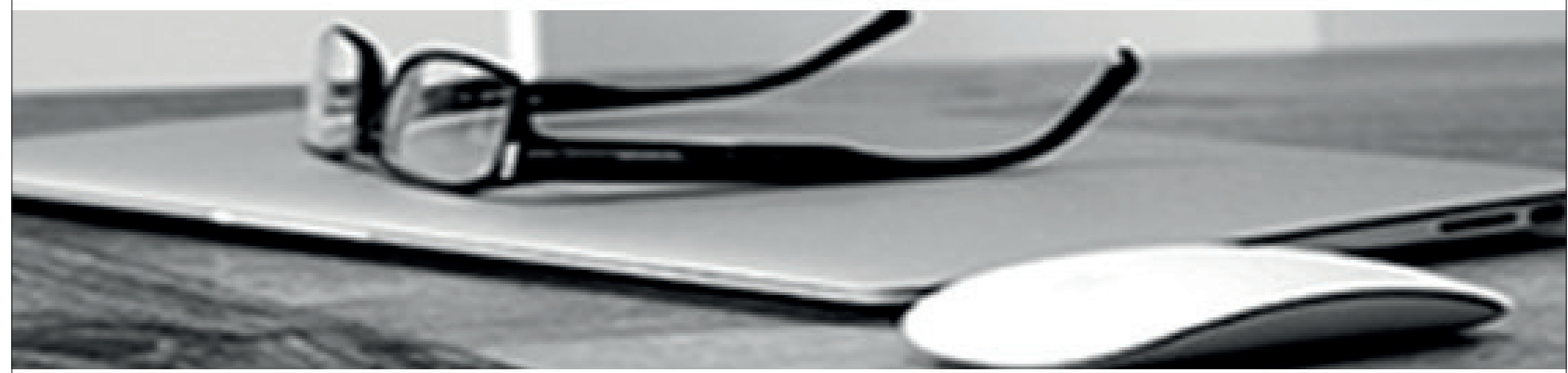

* Consultoría estratégica en gestión y gobierno de la información

* Gestión documental y "records management"

* Gestión de contenidos, intranets corporativas y entornos de colaboración

* Estudios especializados

Clientes satisfechos, cientos de empresas nacionales e internacionales y más de 30 años de experiencia son la mejor garantía de nuestra reputación. 